\title{
Heavy Metal Ion Extraction Using Organic Solvents: An Application of the Equilibrium Slope Method
}

\author{
Tjoon Tow Teng, Yusri Yusup and Ling Wei Low \\ Universiti Sains Malaysia \\ Malaysia
}

\section{Introduction}

The separation procedure of a chemical species from a matrix is essentially based on the transportation of the solute between the two involved phases, generally an organic and an inorganic one. Specifically, solvent extraction uses the concept of unique solute distribution ratios between two immiscible solvents. However, there are several situations where solutes have been observed to completely move from the inorganic to the organic phase (Anthemidis and Ioannou, 2009).

Organic solvent extraction is the transport of solutes, e.g. heavy metal ions, from an inorganic (or aqueous) phase to an organic phase. Solvents used comprise of an extractant + diluent combination. The roles of each are as follows: 1) the extractant, as a specific metal ion extractant; 2) the diluent, as a solvent condition controller, i.e. hydrophobicity, which can affect the molecules extractability (Watson, 1999; Cox, 2004). Occasionally, a phase modifier can be added to solve the problem of emulsion formation, aside from improving the phase demarcation process in an aqueous organic system (Cox, 2008).

Solvent extraction is widely applied to processes of metal ions recovery, ranging from aqueous solutions in hydrometallurgical treatment to environmental applications. It is also considered a useful technique to increase the initial concentration of the solute, commonly used in the separation processes of analytical applications (Reddy et al., 2005).

In the biomedical field, supported liquid membrane methodology was used for trace analytes determination by facilitating chromatogram differentiation between samples, water and blood plasma (Jonsson and Mathiasson, 1999). It is also used to enrich human wastes (e.g. urine) with heavy metals prior to concentration determination using atomic absorption spectroscopy (AAS) (Lindegrade et al., 1992; Djane et al., 1997a; Djane et al., 1997b).

\subsection{Organic solvents}

Numerous organic solvents have been utilized to remove heavy metals (Leopold et al., 2010; Rafighi et al., 2010; Chang et al., 2011; Fu et al., 2011; Mishra and Devi, 2011). Most of them are, in part, made from petroleum. Recently, solvents such as vegetable oil (Venkateswaran 
et al., 2007; Chang et al., 2010), were exploited as alternatives to replace the commonly used petroleum-based organic solvents. Additionally, a family of "specialist" extractants, known as the organo-phosphorous compounds, are also employed as metal extractants (Sainz-Diaz et al., 1996).

Some examples of solvents applied in heavy metals extraction are:

a. Di-2-ethylhexylphosphoric acid (D2EHPA), extensively used as an extractant for the separation of $\mathrm{Cu}$ (II) from aqueous solutions (Gherrou et al., 2002; Ren et al., 2007; Cox, 2008). Other applications of this popular extractant include the removal of $\mathrm{Cd}(\mathrm{II})$ (Kumar et al., 2009), Zn(II) (Vahidi et al., 2009), Fe(III) and Ti(IV) (Silva et al., 2008);

b. Tributylphosphate (TBP), used to act as a phase modifier in $\mathrm{Cu}$ (II) extraction (Cheng, 2000). The extractant and phase modifier are diluted at certain ratios in the petroleumbased organic diluents such as kerosene and chloroform (Ak et al., 2008; Ren et al., 2008), cumene (Svendsen et al., 1990), dichloromethane (Memon et al., 2003), isododecane (Mortes and Bart, 2000), n-dodecane (Simonin et al., 2003), n-decanol (Lin et al., 2005), nheptane (Morais and Mansur, 2004), and n-hexane (Valenzuela et al., 2002);

c. LIX 84 and Cyanex 272, applied to extract $\mathrm{Cu}(\mathrm{II}), \mathrm{Ni}(\mathrm{II})$, and $\mathrm{Al}(\mathrm{III})$ (Mohapatra et al., 2007; Agrawal et al., 2008);

d. Cyanex 921, used to extract $\mathrm{Cu}(\mathrm{II})$ from $\mathrm{HCl}$ (Mishra and Devi, 2011);

e. Miscellaneous organic solvents such as I) 1-phenyl-3-heptyl-1,3-propanedione, II) 1phenyl-4-ethyl-1,3-octanedione, III) 1-(4'-dodecyl) phenyl-3-tert-butyl-1,3-propanedione in kerosene, used to extract $\mathrm{Cu}$ (II) (Fu et al., 2011).

\section{Stoichiometry of heavy metals extracted using organic solvents: Equilibrium slope method}

The equilibrium slope method has been used by many researchers to determine the stoichiometry of various metal-organic complexes in organic solvents (Nagaosa and Yao, 1997; Wang and Nagaosa; 2001; Mansur et al., 2002; Kumar et al., 2009). Most of its applications deal with extracting metal ions from aqueous solutions. It has proven a very useful technique of its ease of use, and its accuracy when validated by other methods, such as numerical and quantitative analysis from Fourier Transform Infrared Spectroscopy (FTIR).

\subsection{General equilibrium slope methodology}

Following this methodology, the extractant form in the organic solvent would need to be estimated first. Subsequently, the formulation of a balanced reaction equation would be derived. A general form of the reaction equation is shown below (Eq. 1). Some applied assumptions include that the solubility of the extractant and the metal-extractant complex in the aqueous phase is small, and that the extracted metal ions are not associated to one another.

$$
M_{(a q)}^{n+}+x H R_{(o r g)} \stackrel{K_{e q}}{\leftrightarrow} M R_{x(o r g)}+x H_{(a q)}^{+}
$$

where, 


$\begin{array}{llll}- & M= & \text { metal ion } \\ - & R= & \text { hydrocarbon group } \\ - & n= & \text { oxidation number } \\ - & x= & \text { stoichiometric coefficient } \\ - & \text { org }= & \text { organic phase } \\ - & K_{\text {eq }}= & \text { equilibrium constant }\end{array}$

The equilibrium constant, $K_{e q}$, can be experimentally determined. In turn, $K_{e q}$ is a function of $D_{e q}$, which is the equilibrium distribution ratio of the metal ion concentration in the organic and the aqueous phase (Eq. 2).

$$
D_{e q}=\left(\frac{M^{n+}{ }_{(o r g)}}{M^{n+}(a q)}\right)_{e q}
$$

During the experiment, the ionic strength and the correlated activity coefficient, $a$, is needed to be kept constant by adding inert chemicals or substances such as salts. A plot of $\lg D_{e q}$ against $\mathrm{pH}_{\mathrm{eq}}$ can be drawn to determine the valency of the extracted metal ion. This information can also be used to ensure the experiment validity by cross-checking the actual valency of the studied metal ion to the slope of the drawn plot. In addition, a plot of $\lg D_{e q}$ versus $\lg$ [extractant], will reveal the value of the stoichiometric coefficient of the extractant, $x$.

\subsection{Application of the equilibrium slope methodology}

In this section a separated study on the equilibrium slope method applied to different metal ions reported in literature is presented.

\subsubsection{Cu (II)}

$\mathrm{Cu}$ (II) extraction from aqueous solutions using different organic solvents have been studied extensively. Combination of extractants and solvents used to extract $\mathrm{Cu}$ (II) from an aqueous solution in literature include D2EHPA + soybean oil (Chang et al., 2010; Chang et al., 2011), LIX 84 + kerosene (Agrawal et al., 2008), Cyanex 921 + kerosene (Leopold et al., 2010; Mishra and Devi, 2011), and Cyanex 272 + kerosene (Mohapatra et al., 2007; Agrawal et al., 2008; St John et al., 2010). The solvents employed are mostly non-polar in nature.

The steps required to determine the stoichiometric coefficient of the extractant are somewhat similar between the extractant + solvent combinations. Thus, the general technique, in sequence, is listed below.

The relevant reaction equation can be written as Eq. (3), where $K_{e q}$ is defined as Eq. (4) and Eq. (5).

$$
\mathrm{Cu}^{2+}{ }_{(a q)}+x H R_{(\text {org })} \stackrel{K_{e q}}{\leftrightarrow} \mathrm{CuR}_{x(\text { org })}+x H^{+}{ }_{(a q)}
$$

where,

$$
K_{e q}=\frac{\left[\mathrm{CuR}_{x}\right]\left[\mathrm{H}^{+}\right]^{x}}{\left[\mathrm{Cu}^{2+}\right][\mathrm{HR}]^{x}}
$$




$$
D_{e q}=\left(\frac{C u^{2+}{ }_{(o r g)}}{\mathrm{Cu}^{2+}(a q)}\right)_{e q}
$$

By substituting Eq. (5) into Eq. (4),

$$
\begin{gathered}
K_{e q}=D_{e q} \frac{\left[H^{+}\right]^{x}}{[H R]^{x}} \\
K_{e q}[H R]^{x}=D_{e q}\left[H^{+}\right]^{x} \\
\lg K_{e q}+x \lg [H R]=\lg D_{e q}+x \lg \left[H^{+}\right]
\end{gathered}
$$

Since,

$$
x \lg \left[H^{+}\right]=-x p H_{e q}
$$

Hence,

$$
\lg D_{e q}=x p H_{e q}+\lg K_{e q}+x \lg [H R]
$$

A plot of $\lg D_{e q}$ versus $p H_{e q}$ is illustrated in Fig. 1. A summary of published slope and intercept values is listed in Table 1 . It can be deduced that the stoichiometric coefficient would generally equal to the charge of the metal ion extracted.

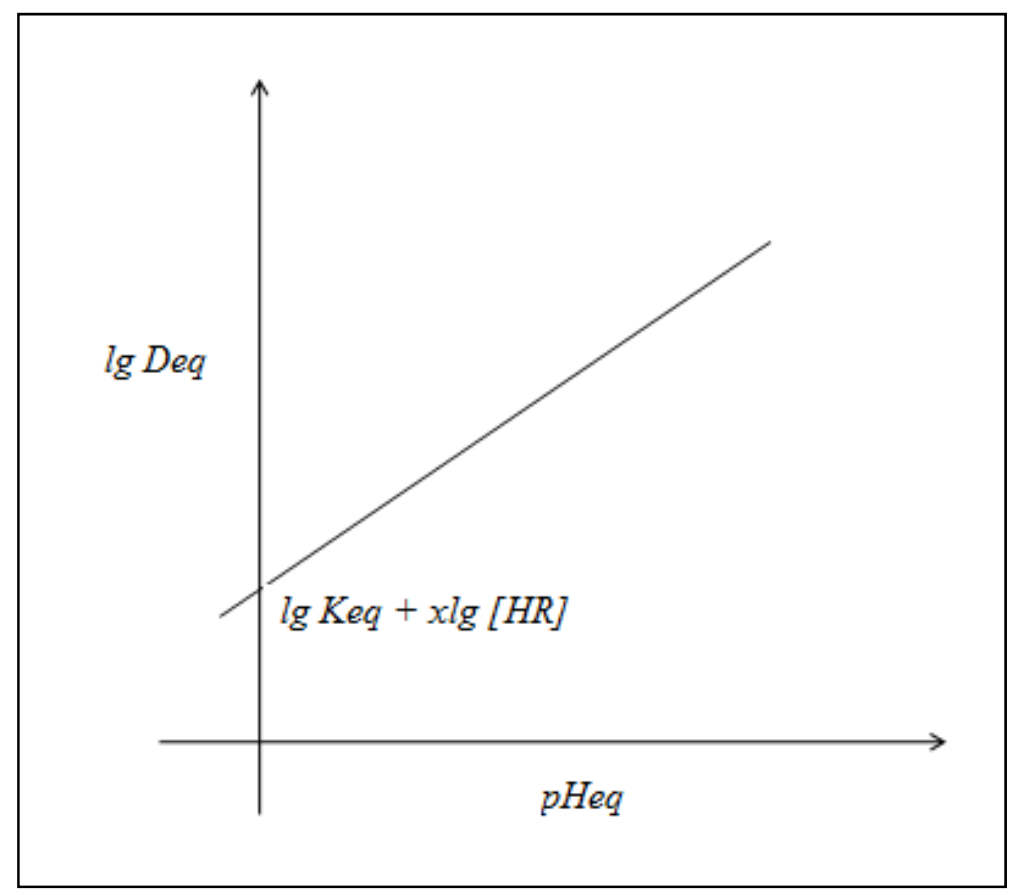

Fig. 1. $\lg D_{e q}$ versus $\mathrm{pH}_{\mathrm{eq}}$ 


\begin{tabular}{|c|c|c|c|c|}
\hline $\begin{array}{l}\text { Extractant + } \\
\text { solvent }\end{array}$ & $x$ & $\begin{array}{l}\lg K_{e q}+x \\
\lg [H R]\end{array}$ & $\begin{array}{l}\text { Extractant formula } \\
\text { with metal }\end{array}$ & Reference \\
\hline $\begin{array}{c}\text { D2EHPA + } \\
\text { soybean }\end{array}$ & 1.99 & -7.12 & $\mathrm{CuR}_{2}(\mathrm{HR})_{2}$ & $\begin{array}{l}\text { Chang et al. } \\
\text { (2011) }\end{array}$ \\
\hline LIX 84 + kerosene & 1.5133 & $\begin{array}{c}-0.9 \\
\text { (estimated) }\end{array}$ & $\mathrm{CuR}_{2}$ & $\begin{array}{c}\text { Agrawal et al. } \\
(2008)\end{array}$ \\
\hline $\begin{array}{l}\text { Cyanex } 921+ \\
\text { kerosene }\end{array}$ & 2.249 & -1.6105 & $\mathrm{CuR}_{2}$ & $\begin{array}{c}\text { Mishra and Devi } \\
\text { (2011) }\end{array}$ \\
\hline $\begin{array}{l}\text { Cyanex } 272+ \\
\text { kerosene }\end{array}$ & 1.75 & $\begin{array}{c}-1 \\
\text { (estimated) }\end{array}$ & $\mathrm{CuR}_{2}$ & $\begin{array}{c}\text { Agrawal et al. } \\
(2008)\end{array}$ \\
\hline
\end{tabular}

Table 1. Slope and intercept of $\lg \mathrm{D}_{\mathrm{eq}}$ versus $\mathrm{pH}_{\mathrm{eq}}$

An average of $1.88 \approx 2$ for the slope has been observed by researchers using non-polar solvents. According to Chang et al. (2011), the $\mathrm{Cu}$ (II) ions were solvated by two simple molecules of D2EHPA, a supposition that stem from the slope obtained using the equilibrium slope method. In conclusion, the number of molecules of the extractant $(\mathrm{HR})_{\mathrm{x}}$ (or R) determined by all researchers was unanimously 2, even when using different extractant and diluent combinations.

\subsubsection{Ni (II)}

Since $\mathrm{Ni}(\mathrm{II})$ has the same oxidation number as $\mathrm{Cu}(\mathrm{II})$ and not much work has been published on the extraction of this metal ion, then it can be assumed that $\mathrm{Ni}$ (II) would behave as $\mathrm{Cu}(\mathrm{II})$ would. A precaution when using this assumption is the type of solvent + extractant combination, which would give variable results on slope and intercept values. These values, in turn, depend on empirical or experimental values. The general reaction equation is written as Eq. (11) and the equilibrium constant as Eq. (12).

$$
\begin{gathered}
N i_{(a q)}^{2+}+x H R_{(o r g)} \stackrel{K_{e q}}{\leftrightarrow} N i R_{x(o r g)}+x H^{+}{ }_{(a q)} \\
K_{e q}=\frac{\left[N i R_{x}\right]\left[H^{+}\right]^{x}}{\left[N i^{2+}\right][H R]^{x}}
\end{gathered}
$$

The results obtained is similar to what has been developed for $\mathrm{Cu}(\mathrm{II})$. This is supported by Tanaka and Alam (2011), which obtained a slope of 2 for $\mathrm{pH}$ between 1 and 4 . Moreover, they found that for $\mathrm{Ni}(\mathrm{II})$, the $\lg D_{e q}$ versus $\mathrm{pH}$ diagram would exhibit 3 regions: I) $\mathrm{pH}<4$; II) $5<\mathrm{pH} \leq 8$; and III) $\mathrm{pH}>8$ (refer to Figure 2). It was also discovered by the latter researchers that at higher initial concentrations of LIX84I, another extractant, would extend the line with slope 2 until a $\mathrm{pH}$ of approximately 5 .

In the $\mathrm{pH}<4$ region, the slope of the $\lg D$ versus $\mathrm{pH}$ curve would be 2 and the $\mathrm{Ni}(\mathrm{II})$ ions would exist as free ions. Thus, the extraction process would result from the ion exchange interaction between $\mathrm{Ni}(\mathrm{II})$ and $2 \mathrm{H}^{+}$(same as $\mathrm{Cu}(\mathrm{II})$ ). For $5<\mathrm{pH} \leq 8$, the slope would be virtually zero and the organic phase would be saturated with the $\mathrm{Ni}(\mathrm{II})$ ions. However, $\mathrm{Ni}(\mathrm{II})$ ions can still be extracted through proton exchange by forming the compound, $\mathrm{NiR}_{2}$ (similar to $\mathrm{Cu}(\mathrm{II})$ ). Still, the $\mathrm{pH}$ needs to be adjusted to achieve this. In the third region, $\mathrm{pH}>$ 8 , the slope would essentially be negative (in this case of extracting $\mathrm{Ni}$ (II) from ammonium solutions) because of the formation of nickel-ammine complexes occurring concurrently with the decrease in free $\mathrm{Ni}$ (II) ion concentrations (Agrawal et al., 2008). 


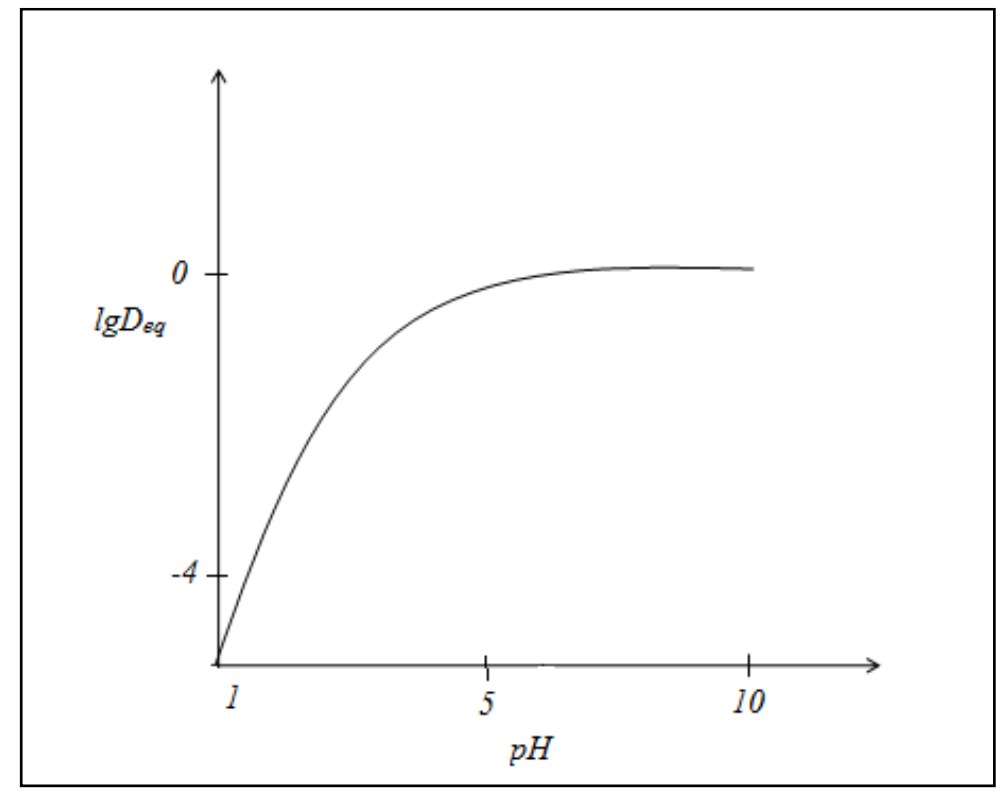

Fig. 2. $\lg D_{e q}$ as a function of $\mathrm{pH}$ at equilibrium

\subsubsection{Cd(II)}

A dimer formation between $\mathrm{Cd}(\mathrm{II})$ ions and an organic group has been suggested by many researchers (Kumar et al., 2009). Thus, the mechanism of extraction of Cd(II) with organic solvents would also behave the same as $\mathrm{Cu}(\mathrm{II})$ and $\mathrm{Ni}(\mathrm{II})$, as previously discussed . Since the researchers postulated a molecular form of the resulting organic complex, they could formulate a specific chemical reaction equation, written as Eq. (13). In the specific case of using D2EHPA + kerosene to extract this metal ion, the researchers have found a slope of 1.9143 and $y$-intercept of 4.5132 between the $\mathrm{pH}$ range of 1 and 5 .

$$
M_{(a q)}^{n+}+(n+p) / 2 \overline{\left(H_{2} R_{2}\right)_{\text {org }}} \stackrel{K_{e q}}{\leftrightarrow} \overline{\left(M R_{n}(H R)_{p}\right)_{\text {org }}}+n H_{a q}^{+}
$$

where,

$p=$ number of molecules of extractant engaged in reaction

Parrus et al. (2011) plotted a $\lg D_{e q}$ versus $\lg$ [extractant] graph to determine the number of organic molecules attached to $\mathrm{Cd}(\mathrm{II})$ following the application of the equilibrium slope method using 1-(2-pyridyl)-tridecan-1-one and 1-(2-pyridyl)-pentadecan-1-ol oximes in chloroform. They found that the slopes are, on average, 2, corroborating the postulate of the previous researchers on the molecular structure of the $\mathrm{Cd}(\mathrm{II})$ organic complex.

\subsection{4 $\mathrm{Cr}$ (III)}

Using the general reaction equation given by Eq. (1) and the steps applied on $\mathrm{Cu}(\mathrm{II})$, the relevant resulting equations are written below (Eq. 14-19). 


$$
\mathrm{Cr}_{(a q)}^{3+}+x H R_{(\text {org })} \stackrel{K_{e q}}{\leftrightarrow} \operatorname{Cr} R_{x(\text { org })}+x H^{+}{ }_{(a q)}
$$

where,

$$
\begin{gathered}
K_{e q}=\frac{\left[C r R_{x}\right]\left[H^{+}\right]^{x}}{\left[C r^{3+}\right][H R]^{x}} \\
D_{e q}=\left(\frac{C r^{3+}{ }_{(o r g)}}{C r^{3+}{ }_{(a q)}}\right)_{e q}
\end{gathered}
$$

By substituting Eq. (16) into Eq. (15),

$$
\begin{gathered}
K_{e q}=D_{e q} \frac{\left[H^{+}\right]^{x}}{[H R]^{x}} \\
K_{e q}[H R]^{x}=D_{e q}\left[H^{+}\right]^{x}
\end{gathered}
$$

Hence,

$$
\lg D_{e q}=x p H_{e q}+\lg K_{e q}+x \lg [H R]
$$

Researchers (Al-Zoubi et al., 2011) have found that for their situation, i.e. a combination of $\mathrm{Cu}(\mathrm{II})$ and $\mathrm{Cr}(\mathrm{III})$ ions in an aqueous solution, only $\mathrm{Cu}(\mathrm{II})$ is the extractable species. A linear relationship was still observed for $\mathrm{Cu}(\mathrm{II})$ and $\mathrm{Cr}(\mathrm{III})$ with a slope of 2 and 0.68 , respectively.

\subsubsection{Zn(II)}

Baba and Adekola (2011) proposed the general reaction equation, Eq. (1), for metals Zn, Cd, $\mathrm{Co}, \mathrm{Fe}, \mathrm{Pb}, \mathrm{Ca}$, and $\mathrm{Mg}$ when using D2EHPA. They stated that the extraction process depends on solution composition, equilibrium, $\mathrm{pH}$, and type of diluents, while the increase in proton concentrations would further promote this reaction. Mellah and Benarchour (2006) proposed a specific reaction equation for $\mathrm{Zn}(\mathrm{II})$ when extracting it using D2EHPA written as Eq. (20) based on the assumptions that extractant molecules exist as dimers in the solvent (kerosene in their work). They obtained a slope of 1.7152 and 1.7153 for $0.1 \mathrm{M}$ and $0.2 \mathrm{M}$ of D2EHPA, respectively.

$$
\mathrm{Zn}^{2+}{ }_{(a q)}+1.5\left(\mathrm{H}_{2} R_{2}\right)_{(\text {org })} \stackrel{K_{\text {eq }}}{\longrightarrow} \mathrm{ZnR} R_{2}(\mathrm{HR})_{\text {org }}+2 \mathrm{H}^{+}{ }_{(a q)}
$$

Since the general reaction equation is applicable for $\mathrm{Zn}(\mathrm{II})$ and shown by Baba and Adekola (2011) as well, a slope of approximately 2 would be evident from the $\lg D_{e q}$ versus $\mathrm{pH}$ plot. The latter authors reported a slope of 1.86. Li et al. (2003) has also reported a close to 2 value of 1.92 when extracting $\mathrm{Zn}(\mathrm{II})$ using Cyanex 272

\subsubsection{U(VI)}

Even though the oxidation number of $\mathrm{U}(\mathrm{VI})$ is more than 2, in the work published by St John et al. (2010) it was found that the slope of the $\lg \mathrm{D}_{\mathrm{eq}}$ versus $\mathrm{pH}$ plot is 2.10. This is due to $\mathrm{U}(\mathrm{VI})$ forming a complex with $\mathrm{O}_{2}$ that results in the formation of $\mathrm{UO}_{2}{ }^{2+}$, thus the equilibrium slope of 2 . 


\subsubsection{Co(II)}

The reaction equation and the related equilibrium constant for the extraction of $\mathrm{Co}(\mathrm{II})$ using Cyanex 272 are written as Eq. (21-25) (Parhi et al., 2008). A slope of 2.0282 was obtained, proving that the extracted species was $\mathrm{CoR}_{2}$.

$$
\mathrm{Co}_{(a q)}^{2+}+x H R_{(o r g)} \stackrel{K_{e q}}{\leftrightarrow} \operatorname{CoR}_{x(\text { org })}+x H^{+}(a q)
$$

where,

$$
\begin{gathered}
K_{e q}=\frac{\left[\mathrm{CoR}_{x}\right]\left[\mathrm{H}^{+}\right]^{x}}{\left[\mathrm{Co}^{2+}\right][\mathrm{HR}]^{x}} \\
D_{e q}=\left(\frac{\mathrm{Co}^{2+}{ }_{(\text {org })}}{\mathrm{Co}^{2+}{ }_{(a q)}}\right)_{e q}
\end{gathered}
$$

By substituting Eq. (23) into Eq. (22),

$$
K_{e q}[H R]^{x}=D_{e q}\left[H^{+}\right]^{x}
$$

Hence,

$$
\lg D_{e q}=x p H_{e q}+\lg K_{e q}+x \lg [H R]
$$

In another study by Rafighi et al. (2010), a different reaction equation was proposed (Eq. 26) Plots of $\lg D_{e q}$ versus $\lg$ [extractant] showed slopes of 1 and 2, pertaining to the number of organic molecules attached to $\mathrm{Co}(\mathrm{II})$.

$$
\mathrm{Co}_{(a q)}^{2+}+\mathrm{HR}^{1(2)}{ }_{(\mathrm{org})}+\mathrm{Cl}^{-}(a q) \leftrightarrow \mathrm{CoR}^{1(2)} \mathrm{Cl}_{3} 3 \mathrm{H}_{2} \mathrm{O}_{(\mathrm{org})}+\mathrm{H}^{+}{ }_{(a q)}
$$

\subsubsection{Al(III)}

In a paper by Mohapatra et al. (2007), $\mathrm{Al}(\mathrm{III})$ was extracted using Na-Cyanex 272 and NaD2EHPA. The slopes of the $\lg D_{e q}$ versus $\mathrm{pH}$ are 1.85 and 2.40 for the two solvents, respectively. The reaction equation is written below (Eq. 27-31). Notice the stoichiometric coefficient of $\mathrm{H}^{+}$is 3 .

$$
\begin{gathered}
A l^{3+}+n[H R]_{2} \stackrel{K_{e q}}{\leftrightarrow} A l H_{2 n-3} R_{2 n}+3 H^{+} \\
K_{e q}=\frac{\left[A l H_{2 n-3} R_{2 n}\right]\left[H^{+}\right]^{3}}{\left[A l^{3+}\right][H R]_{2}^{n}} \\
K_{e q}=\frac{D_{e q}\left[H^{+}\right]^{3}}{[H R]_{2}^{n}}
\end{gathered}
$$

where,

$$
D_{e q}=\frac{\left[A l H_{2 n-3} R_{2 n}\right]}{\left[A l^{3+}\right]}
$$

Hence,

$$
\lg D_{e q}=\lg K_{e q}+n \lg [H R]_{2}-3 \lg \left[H^{+}\right]
$$




\section{Other methods to determine stoichiometry of heavy metals extraction using organic solvents}

There are other methods that can be used to validate the stoichiometry of the organic complexes produced from the heavy metal extraction process using organic solvents. These methods include numerical analysis and quantitative analysis using FTIR.

Numerical analysis requires that a multiple regression analysis be conducted using a first order function, written as Eq. (32).

$$
y=\beta_{0}+\sum_{i=1}^{k} \beta_{i} x_{i}+\varepsilon
$$

where,

$\begin{array}{ll}- & \beta_{0}= \\ - & \beta_{i}= \\ - & y= \\ - & x_{i}= \\ - & \varepsilon=\end{array}$

constant for intercept

constant for linear variables

dependent variable

independent variable

error term

This is followed by a best fit exercise using the least square method. As an example, albeit a very specific one and since this analysis is highly empirical in nature, constants can be estimated, along with the corresponding standard deviation, $\mathrm{t}$ and probability $(\mathrm{P})$ values, for the variable terms of a regression model of $\log \mathrm{D}_{\text {eq. }}$. At a $5 \%$ significance level, all variable terms, when found to have $\mathrm{P}<0.05$, are thus considered statistically significant. Hence, a firstorder polynomial model that correlates $\log \mathrm{D}_{\mathrm{eq}}$ with all the variable terms can be developed.

The adequacy or goodness of fit of the regression model can be analyzed using analysis of variance (ANOVA) at a 5\% significance level. Low $\mathrm{P}(\mathrm{P}<0.05)$ value of the regression model indicates that it is statistically significant. To test the global fit of the model, the coefficient of determination $\left(\mathrm{r}^{2}\right)$ can also be evaluated. Small deviations between the $\mathrm{r}^{2}$ and adjusted $\mathrm{r}^{2}$ values would imply that there is less chance for the inclusion of any insignificant terms in the model and that the model is highly significant.

Since Eqs. (32) and (10) are of the same forms, their constants for each variable term can be compared conveniently. By evaluating the constants of $\log \left[(\mathrm{HR})_{2}\right]$ from Eq. (4), i.e. $(2+\mathrm{m}) / 2$, with that from the regression model, the $\mathrm{m}$ value can be determined and, thus, brings about the stoichiometric ratio.

Chang et al. (2011) has used this method to confirm that the slope of the $\lg D_{e q}$ versus $\mathrm{pH}$ is $2(=1.988)$.

Quantitative analysis using FTIR requires an FTIR analysis of the metal ion-loaded organic solvent. This is detailed in the paper by Sainz-Diaz et al. (1996). For the case of $\mathrm{Cu}(\mathrm{II})$ and D2EHPA, it leverages the fact that there is a highly polar phosphoryl bond $(\mathrm{P}=\mathrm{O})$ in the D2EHPA compound and could easily react with $\mathrm{Cu}(\mathrm{II})$. Knowing that the absorbance of the $\mathrm{P}=\mathrm{O}$ band is at $1235 \mathrm{~cm}^{-1}$ at multiple concentrations of D2EHPA standard solutions, a calibration curve can be obtained. This calibration curve can be used to determine the concentration of D2EHPA that did not react with $\mathrm{Cu}(\mathrm{II})$. By finding the difference between the reacted and unreacted concentrations of D2EHPA, the concentration of Cu-D2EHPA (organic complex) can be estimated. A plot of the Cu-D2EHPA versus the organic concentration of $\mathrm{Cu}$ will reveal the slope that corresponds to the constant stochiometic ratio of D2EHPA. 


\section{Conclusion}

Liquid extraction of heavy metals is widely applied in many fields ranging from the environmental to the biomedical discipline. In the environmental field, some of the more prominent applications include: removal and recovery of heavy metals and dyes from wastewater. In the biomedical field, liquid extraction has been used in the determination of heavy metals in human waste (e.g. urine). However, trace analytes extraction is still a great challenge in the pharmaceutical and medical industry.

In this chapter, the equilibrium slope method and its utility in estimating the stoichiometry of the resulting organic complexes has been reviewed for multiple heavy metal ions. The number of protons involved generally dictates the slope of the $\lg D_{e q}$ versus $\mathrm{pH}$ plot. A slope of 2 is common for many heavy metals, thus attributing that the general organic complexes obtained from these extraction processes are in the form of dimers.

In brief other methods, numerical and FTIR quantitative analysis have been discussed and might be helpful to further corroborate the results of the equilibrium slope method.

\section{References}

Agrawal, A.; Manoj, M.K., Kumari, S., Bagchi, D., Kumar, V. \& Pandey, B.D. (2008). Extractive separation of copper and nickel from copper bleed stream by solvent extraction route. Minerals Engineering, Vol.21, pp. 1126-1130.

Ak, M.; Taban, D. \& Deligoz, H. (2008). Transition metal cations extraction by ester and ketone derivatives of chromogenic azocalix arenes. Journal of Hazardous Materials, Vol.154, pp. 51-52.

Al-Zoubi, W.; Kandil, F. \& Chebani, M.K. (2011). Solvent extraction of chromium and copper using Schiff base derived from terephthaldialdehyde and 5-amino-2-methoxy phenol. Arabian Journal of Chemistry, Article in Press DOI:10.1016/j.arabjc. 2011.06.023

Anthemidis, A.N. \& Ioannou, K.G. (2009). Recent development in homogenous and dispersive liquid-liquid extraction for inorganic elements determination. A review. Talanta, Vol.80, pp. 413-421.

Baba, A.A. \& Adekola, F.A. (2011). Beneficiation of a Nigerian sphalerite mineral: solvent extraction of zinc by Cyanex 272 in hydrochloric acid. Hydrometallurgy, Vol. 109, pp. 187-193.

Chang, S.H.; Teng, T.T. \& Norli, I. (2010). Extraction of $\mathrm{Cu}(\mathrm{II})$ from aqueous solutions by vegetable oil-based organic solvents. Journal of Hazardous Materials, Vol.181, pp. 868-872.

Chang, S.H.; Teng, T.T. \& Norli, I. (2011). Efficiency, stoichiometry and structural studies of $\mathrm{Cu}(\mathrm{II})$ removal from aqueous solutions using di-2-ethylhexylphosphoric acid and tributhylphosphate diluted in soybean oil. Chemical Engineering Journal, Vol.166, pp. 249-255.

Cheng, C.Y. (2000). Purification of synthetic laterite leach solution by solvent extraction using D2EHPA. Hydrometallurgy, Vol.56, pp. 369-386.

Cox, M. (2004). Solvent extraction in hydrometallurgy, In: J. Rydberg, M. Cox, C. Musikas, G.R. Choppin (Eds.), Solvent Extraction Principles and Practice, Marcel Dekker Inc., The United States of America, pp. 457-462.

Cox, M. (2008). Liquid-liquid extraction and liquid membranes in the perspective of the twenty-first century, In: M. Aguilar, J.L. Cortina (Eds.), Solvent Extraction and Liquid Membranes Fundamentals and Applications inNewMaterials, CRC Press, the United States of America, pp. 1-19. 
Djane, N.K.; Bergdahl, I.A.; Ndung's, K.; Schutz, A.; Johansson, G. \& Mathiasson, L. (1997a). Supported liquid membrane enrichment combined with atomic absorption spectrometry for the determination of lead in urine. Analyst, Vol.122, pp.1073-1077.

Djane, N.K.; Ndung'u, K.; Malcus, F.; Johansson, G. \& Mathiasson, L. (1997b). Supported liquid membrane enrichment using an organophosphorus extractant for analytical trace metal determinations in river waters. Fresenius' Journal of Analytical Chemistry, Vol.358, pp.822

Fu, W.; Chen, Q., Hu, H., Niu, C. \& Zhu, Q. (2011). Solvent extraction of copper from ammoniacal chloride solutions by sterically hindered $\beta$-diketone extractants. Separation and Purification Technology, Vol.80, pp. 52-59.

Gherrou, A.; Kerdjoudj, H., Molinari, R. \& Drioli, E. (2002). Removal of silver and copper ions acidic thiourea solutions with a supported liquid membrane containing D2EHPA as carrier, Separation and Purification Technology, Vol.28, pp. 235-244.

Jonsson, J.A. \& Mathiasson, L. (1999). Liquid membrane extraction in analytical sample preparation II: Applications. Trends in Analytical Chemistry, Vol.18, pp. 325-334.

Kumar, V.; Kumar, M., Jha, M.K., Jeong, J. \& Lee, J. (2009). Solvent extraction of cadmium from sulfate solution with di(2-ethylhexyl)phosphoric acid diluted in kerosene. Hydrometallurgy, Vol.96, pp. 230-234.

Leopold, A.A.; Coll, M.T., Fortuny, A., Rathore, N.S. \& Sastre, A.M. (2010). Mathematical modelling of cadmium (II) solvent extraction from neutral and acidic chloride media using Cyanex 923 extractant as a metal carrier. Journal of Hazardous Materials, Vol.182, pp. 903-911.

Li, D.Q.; Wang, L.G. \& Wang, Y.G. (2003). Synergistic extraction of Zinc(II) with mixtures of CA-100 and Cyanex 272. Separation Science and Technology, Vol.38, pp. 2291-2306.

Lin, S.H.; Kao, H.C., Su, H.N. \& Juang, R.S. (2005). Effect of formaldehyde on Cu(II) removal from synthetic complexed solutions by solvent extraction. Journal of Hazardous Materials, Vol.120, pp. 1-3.

Lindegrad, B.; Jonsson, J.A. \& Mathiasson, L. (1992). Liquid membrane work-up of blood plasma samples applied to gas chromatographic determination of aliphatic amines. Journal of Chromatography, Vol.573, pp.191-200.

Mansur, M.B.; Slater, M.J. \& Biscaia Jr, E.C. (2002). Equilibrium analysis of the reactive liquidliquid test system $\mathrm{ZnSO}_{4}$ / D2EHPA/n-heptane. Hydrometallurgy, Vol.63, pp. 117-126.

Mellah, A. \& Benachour, D. (2006). The solvent extraction of zinc and cadmium from phosphoric acid solution by di-2-ethylhexyl phosphoric acid in kerosene diluent. Chemical Engineering and Processing, Vol.45, pp. 684-690.

Memon, S.; Akceylan, E., Sap, B., Tabakci, M., Roundhill, D.M. \& Yilmaz, M. (2003). Polymer supported calyx arene derivatives for the extraction of metals and dichromate anions. Journal of Polymer and Environment, Vol.11, pp. 67-69.

Mishra, S. \& Devi, N. (2011). Extraction of copper (II) from hydrochloric acid solution by Cyanex 921. Hydrometallurgy, Vol.107, pp. 29-33.

Mohapatra, D.; Kim, H.I., Nam, C.W. \& Park, K.H. (2007). Liquid-liquid extraction of aluminium (III) from mixed sulphate solutions using sodium salts of Cyanex 272 and D2EHPA. Separation and Purification Technology, Vol.56, pp. 311-318.

Morais, B.S. \& Mansur, M.B. (2004). Characterization of the reactive test system ZnSO4/D2EHPA in n-heptane, Hydrometallurgy, Vol.74, pp. 11-18.

Mortes, M. \& Bart, H.J. (2000). Extraction equilibria of zinc with bis(2 ethylhexyl)phosphoric acid. Journal of Chemical Engineering Data, Vol.45, pp. 82-85.

Nagaosa, Y. \& Yao, B.H. (1997). Extraction equilibria of some transition metal ions by bis(2ethylhexyl)phosphoric acid. Talanta, Vol.44, pp. 327-337. 
Parhi, P.K.; Panigrahi, S., Sarangi, K. \& Nathsarma, K.C. (2008). Separation of cobalt and nickel from ammoniacal sulphate solution using Cyanex 272. Separation and Purification Technology, Vol. 59, pp. 310-317.

Parus, A.; Wieszczycka, K., Olszanowski, A. (2011). Solvent extraction of cadmium (II) from chloride solutions by pyridyl ketoximes. Hydrometallurgy, Vol.105, pp. 284-289.

Rafighi, P.; Yaftian, M.R. \& Noshiranzadeh, N. (2010). Solvent extraction of cobalt (II) ions; cooperation of oximes and neutral donors. Separation and Purification Technology, Vol.75, pp. 32-38.

Reddy, B.R.; Priya, D. N., Rao, S.V. \& Radhika, P. (2005). Solvent extraction and separation of $\mathrm{Cd}(\mathrm{II}), \mathrm{Ni}(\mathrm{II})$ and $\mathrm{Co}(\mathrm{II})$ from chloride leach liquors of spent $\mathrm{Ni}-\mathrm{Cd}$ batteries using commercial organo-phosphotus extractants. Hydrometallurgy, Vol. 77, pp. 253-261.

Ren, Z.; Zhang, W., Meng, H., Liu, Y.M. \& Dai, Y. (2007). Extraction equilibria of copper(II) with D2EHPA in kerosene from aqueous solutions in acetate buffer media. Journal of Chemical Engineering Data, Vol.52, pp. 438-441.

Ren, Z.Q.; Zhang, W., Dai, Y., Yang, Y. \& Hao, Z. (2008). Modeling of effect of pH on mass transfer of copper(II) extraction by hollow fiber renewal liquid membrane. Industrial Engineering Chemistry and Research, Vol.47, pp. 4256-4262.

Sainz-Diaz, C.I.; Klocker, H., Marr, R. \& Bart, H.J. (1996). New approach in the modelling of the extraction equilibrium of zinc with bis-(2ethylhexyl) phosphoric acid. Hydrometallurgy, Vol.42, pp. 1-11.

Silva, G.C.; Cunha, J.W.S.D., Dweck, J. \& Afonso, J.C. (2008). Liquid-liquid extraction (LLE) of iron and titanium by bis-(2-ethyl-hexyl)phosphoric acid D2EHPA). Mineral Engineering, Vol.21, pp. 416-419.

Simonin, J.P.; Hendrawan, H., Dardoize, F. \& Clodic, G. (2003). Study of salt effects on the kinetics of extraction of cobalt(II) and zinc(II) at trace level by D2EHPA in ndodecane. Hydrometallurgy, Vol.69, pp. 23-25.

St John, A.M.; Cattrall, R.W. \& Kolev, S.D. (2010). Ectraction of uranium (VI) from sulphate solutions using a polymerinclusion membrane containing di-(2-ethylhexyl) phosphoric acid. Journal of Membrane Science, Vol.364, pp. 354-361.

Svendsen, H.F.; Schei, G. \& Osman, M. (1990). Kinetics of extraction of Zn by di(2ethylhexyl)phosphoric acid in cumene. Hydrometallurgy, Vol.25, pp. 197-212.

Tanaka, M. \& Alam, S. (2010). Solvent extraction equilibria of nickel from ammonium nitrate solution with LIX84I. Hydrometallurgy, Vol.105, pp. 134-139.

Vahidi, E.; Rashchi, F. \& Moradkhani, D. (2009). Recovery of zinc from an industrial zinc leach residue by solvent extraction using D2EHPA. Mineral Engineering, Vol.22, pp. 204-206.

Valenzuela, F.; Vega, M.A., Yanez, M.F. \& Basualto, C. (2002). Application of amathematical model for copper permeation from a Chilean mine water through a hollow fibertype supported liquid membrane. Journal of Membrane Science, Vol.204, pp. 385-387.

Venkateswaran, P.; Gopalakrishnan, A.N. \& Palanivelu, K. (2007). Di(2- ehtylhexyl) phosphoric acid-coconut oil supported liquid membrane for the separation of copper ions from copper plating wastewater. Journal of Environmental Science, Vol.19, pp. 1446-1453.

Wang, T. \& Nagaosa, Y. (2001). Solvent extraction equilibrium of copper (II) with diisodecylphosphoric acid in heptanes and dodecane. Analytical Science, Vol.17, pp. 401-404.

Watson, J.S. (1999). Separation Methods for Waste and Environmental Applications, Marcel Dekker Inc., The United States of America. 


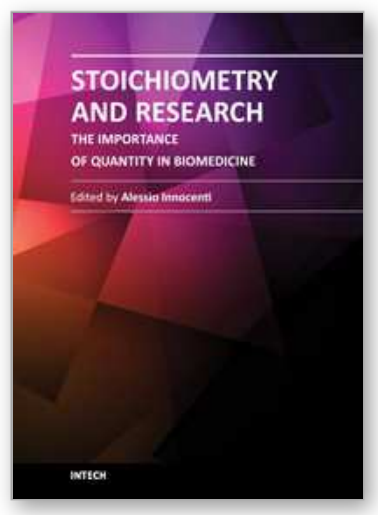

\section{Stoichiometry and Research - The Importance of Quantity in Biomedicine}

Edited by Dr Alessio Innocenti

ISBN 978-953-51-0198-7

Hard cover, 376 pages

Publisher InTech

Published online 07, March, 2012

Published in print edition March, 2012

The aim of this book is to provide an overview of the importance of stoichiometry in the biomedical field. It proposes a collection of selected research articles and reviews which provide up-to-date information related to stoichiometry at various levels. The first section deals with host-guest chemistry, focusing on selected calixarenes, cyclodextrins and crown ethers derivatives. In the second and third sections the book presents some issues concerning stoichiometry of metal complexes and lipids and polymers architecture. The fourth section aims to clarify the role of stoichiometry in the determination of protein interactions, while in the fifth section some selected experimental techniques applied to specific systems are introduced. The last section of the book is an attempt at showing some interesting connections between biomedicine and the environment, introducing the concept of biological stoichiometry. On this basis, the present volume would definitely be an ideal source of scientific information to researchers and scientists involved in biomedicine, biochemistry and other areas involving stoichiometry evaluation.

\section{How to reference}

In order to correctly reference this scholarly work, feel free to copy and paste the following:

Tjoon Tow Teng, Yusri Yusup and Ling Wei Low (2012). Heavy Metal lon Extraction Using Organic Solvents: An Application of the Equilibrium Slope Method, Stoichiometry and Research - The Importance of Quantity in Biomedicine, Dr Alessio Innocenti (Ed.), ISBN: 978-953-51-0198-7, InTech, Available from: http://www.intechopen.com/books/stoichiometry-and-research-the-importance-of-quantity-inbiomedicine/stoichiometry-of-metal-complexes-extracted-using-organic-solvents

\section{INTECH}

open science | open minds

\section{InTech Europe}

University Campus STeP Ri

Slavka Krautzeka 83/A

51000 Rijeka, Croatia

Phone: +385 (51) 770447

Fax: +385 (51) 686166

www.intechopen.com

\section{InTech China}

Unit 405, Office Block, Hotel Equatorial Shanghai

No.65, Yan An Road (West), Shanghai, 200040, China 中国上海市延安西路65号上海国际贵都大饭店办公楼405单元

Phone: +86-21-62489820

Fax: +86-21-62489821 
(C) 2012 The Author(s). Licensee IntechOpen. This is an open access article distributed under the terms of the Creative Commons Attribution 3.0 License, which permits unrestricted use, distribution, and reproduction in any medium, provided the original work is properly cited. 